American Journal of Applied Sciences 6 (4): 551-554, 2009

ISSN 1546-9239

(C) 2009 Science Publications

\title{
Use of Jiben Seeds Extract to Manufacture Soft White Cheese
}

\author{
${ }^{1}$ Mohamed A. Talib, ${ }^{2}$ M.M. Abubakar, ${ }^{2}$ I.A. Jideani and ${ }^{3}$ Ahmed Hassan \\ ${ }^{1}$ Department of Biology, Ndjamena University Faculty of Pure and Applied Science, \\ Ndjamena, Chad, 1027 \\ ${ }^{2}$ Department of Animal Science, Abubakar T.B. University, School of Agriculture, \\ Bauchi, Nigeria, 0248 \\ ${ }^{3}$ Department of Chemistry, Faculty of Science, Assiut University, Assiut, Egypt, 71516
}

\begin{abstract}
Rennet substitute was applied for preparation of white cheese with Jiben (Solanum dubium seeds extract). Time effect $0,15,30,45,60,75,90,120$ and 150 days was studied at $30^{\circ} \mathrm{C}$ on the prepared cheese, kept at room temperature as well as in the refrigerator at $5 \pm 1{ }^{\circ} \mathrm{C}$. Cheese analysis includes $\mathrm{pH}$ and the percentage content of moisture, salt, fat and protein. Use of Rennet to manufacture white cheese was served as a control. Results and statistical analysis indicated that, cheese prepared using Jiben Extract has high quality with a very small variations as well as it has a long storage time. Thus, Solanum dubium is a suitable extract for preparation of white cheeses with a long storage time in the refrigerator $5^{\circ} \mathrm{C}$ as well as at room temperature $30^{\circ} \mathrm{C}$.
\end{abstract}

Key words: Soft cheese, Solanum dubium, preparation, chemical properties

\section{INTRODUCTION}

The contributions of cheese as source of proteins, calories, minerals and some vitamins ${ }^{[1]}$ are vital to the development of a good health. White pickled cheese is a soft white cheese made in Sudan and is similar to Domiati Cheese ${ }^{[2]}$. It is usually made from raw milk containing 6-20\% $\mathrm{NaCl}^{[3,4,5]}$.A number of developments take place in other parts of the world to reach the farm level cheese producers in many parts of Africa. Coagulants such as rennet are still not available in rural areas of Chad, where most of the cheese is produced. Rennet is the most desirable enzyme for coagulation milk to manufacture cheese as well as, it is important in the formation of the casein network during coagulation ${ }^{[6]}$. A shortage of this enzyme has occurred as the decrease in general availability of sucking calves as they are left for beef, thus decreasing the rennet availability and increasing its $\cos ^{[7]}$. This prompted us to use Jiben seed extract in the production of white pickled cheese. Also, storage period effect on cheese analyses at different intervals was done for 150 days.

\section{MATERIALS AND METHODS}

All chemical used were of BDH grade and redistilled water used for the preparation of all solutions. Glassware was soaked in $10 \%(\mathrm{v} / \mathrm{v}) \mathrm{HNO}_{3} 24 \mathrm{~h}$ and rinsed three times with distilled water and then re- distilled water before used. All solutions were prepared by dissolving the appropriate weight for each in redistilled water and standardized according to standard methods ${ }^{[9]}$.

Source of milk: Milk was obtained from herds of white Fulani and red Bororo in Ndjamena, Chad and Bauchi, Nigeria. Milk was collected using 20 liter capacity plastic containers and transported to the laboratory.

Source of Jiben seeds: The dried seeds of Jiben were collected from the surrounding bushes of Ndjamena during the month of January threshed, decorticated manually and stored in the refrigerator until required ${ }^{[10]}$.

\section{Extraction of Jiben Seeds ${ }^{[10]}$ :}

- Extraction with water: $15.0 \mathrm{~g}$ of Solanum dubium seeds and $8.0 \mathrm{~g}$ sodium chloride were dipped in $250 \mathrm{ml}$ flask containing $100 \mathrm{ml}$ re-distilled water for two days at room temperature.

- Extraction with Buffer Solutions: 15.0 g Solanum dubium seeds were extracted in $100 \mathrm{~mL}$ of citrate phosphate buffer ${ }^{[11]}$ (pH's 3.6, 4.6, 5.6 and 6.6) containing $8.0 \mathrm{~g}$ sodium chloride. Extracts were stirred using continuous automatic shaker at $25^{\circ} \mathrm{C}$ with speed of 150 rotator $\min ^{-1}$ for $3 \mathrm{~h}$. The resulting solutions centrifuged at 3000 rotator

Corresponding Author: Ahmed Hassan, Department of Chemistry, Faculty of Science, Assiut University, Assiut, Egypt, 71516 
$\min ^{-1}$ for $5 \mathrm{~min}$ and the precipitate removed. The resulting filtrates divided into $150 \mathrm{ml}$ portions in dark brown bottles and stored at both room temperature and in the refrigerator until required.

Production of White Pickled Cheese: The cheese was produced according to the following procedure ${ }^{[12]}$.

- $20 \mathrm{~kg}$ of fresh cow milk was heated at $61^{\circ} \mathrm{C}$ for 30 min and then cooled to $45^{\circ} \mathrm{C}$

- At the rate of $2.0 \% \mathrm{w} / \mathrm{v}$, starter culture of lactobacillus lactic was added and left for $30 \mathrm{~min}$ to develop acidity

- Extraction of $15 \mathrm{~g}$, Jiben seeds in $100 \mathrm{ml}$ water containing $8 \mathrm{~g} \mathrm{NaCl}$ were added to the milk at the rate of $2 \mathrm{ml} \mathrm{kg}^{-1}$ (Rennet was used as a control)

- The milk was mixed and left to coagulate for 45 $\min$

- $\quad$ The curd was cut vertically and horizontally into 1 $\mathrm{cm}^{3}$ with a sharp knife.

- The whey obtained from the cheese curd was drained and curd was added into small cylindrical moulds lined with cloth and pressed lightly overnight

- The curd was cut into cups of $3 \times 3 \times 3 \mathrm{~cm}^{3}$ and placed in glass Jars, then filled with whey containing $15 \% \mathrm{NaCl}(\mathrm{w} / \mathrm{v})$ and sealed.

Cheese Analysis:

Hydrogen ion concentration, $\mathbf{p H}$ : $\mathrm{pH}$ values were measured with a Fischer (Pittsburgh, PA) Digital pH Meter Model 810.

Moisture: Mortelli ${ }^{[13]}$ suggested that moisture in cheese was measured by Karl Fischer method.

Salt, fat and protein: Salt: (Mohr method) and fat (Babcock method) were determined according to standard methods ${ }^{[14]}$. The Kjeldahl method ${ }^{[15]}$ was used for protein determination as described in the Association of Official Analytical Chemists (AOAC) ${ }^{[16]}$ with the modifications ${ }^{[17]}$. One gram of sample was used and $15 \mathrm{ml} \mathrm{H}_{2} \mathrm{SO}_{4}$ were added followed by two tablets (Kjeltabs-175 mg $\mathrm{HgO}$ and $3.5 \mathrm{~g} \mathrm{~K}_{2} \mathrm{SO}_{4}$ in each tablet). The mixture was digested for $45 \mathrm{~min}$. using a Kjeltec digester (Tecator 1015 digester. Fisher Scientific Pittsburgh PA). After the sample was cooled, $10 \mathrm{ml}$ of sodium thiosulfate $(80 \mathrm{~g}$ in $1 \mathrm{~L}$ re-distilled water) were added. Boric acid $(25 \mathrm{ml})$ was used to receive the distillate which was then titrated with $0.1 \mathrm{~N}$ $\mathrm{HCl}$. Protein (\%) was calculated using a conversion factor of 6.38 .
Statistical analysis: Statistical analysis involving Standard Error (SE), level of significance (LS) and Least Significant Difference (LSD) were performed using statistical analysis system (SAS) ${ }^{[8]}$.

\section{RESULTS AND DISCUSSION}

The measurement of $\mathrm{pH}$ is very important in many aspects of chemical analysis ${ }^{[18]}$. A specially designed voltammeter called a $\mathrm{pH}$ meter. The $\mathrm{pH}$ meter was standardized (calibrated) with the use of buffer solutions with $\mathrm{pH}$ values of 4.0 and 7.0 standardization. Then $\mathrm{pH}$ of each sample solution was determined. $\mathrm{pH}$ values at $30^{\circ} \mathrm{C}$ of prepared cheese by Jiben seeds extract and rennet extract kept at $30^{\circ} \mathrm{C}$ or in refrigerator are presented in Table 1. These values were between 4.3-6.0 indicating all cheese samples were slightly acidic. The average value of $\mathrm{pH}$ decreased during the first month, then increased during the second month. After two months decreased slightly and mainly kept constant after four months. The decrease in $\mathrm{pH}$ can be attributed to microorganisms that possibly survived for a few weeks in the centre of the cheese and cause a slight variation of $\mathrm{pH}$ over the first two weeks ${ }^{[5]}$. The slightly decrease in $\mathrm{pH}$ values may be attributed to slightly acidic effect produced from decomposition of some fat and protein to fatty acids and amino acids respectively, as shown in Table 1.

Moisture: The results of moisture indicate that, the moisture contents of cheeses made with Jiben seeds extract are less than that made with rennet extract kept at room temperature or at refrigerator. The average percentage of the moisture contents were in the range of 4.25-5.57 and 5.13-5.92 respectively as shown in Fig. 1 and 2 , curves $\mathrm{a}_{1}$ and $\mathrm{a}_{2}$ respectively $(\mathrm{SE}=1.29)$.

Curves indicate that, moisture content of both cheese samples decreased rapidly from the first two weeks of pickling period, then decreased gradually as pickling period advanced up 75 days of pickling period, finally, slight decrease was noticed during the last two months of picking period. These results are in agreement with those reported ${ }^{[19-21]}$. The decrease of moisture content during pickling period might attributed to the contraction of cheese curd as a result of developing acidity throughout the pickling period, which helps to expel the whey from cheese curd and the effect of osmotic pressure on brine solution.

Salt: The salt concentration and its distribution in the cheese mass are important parameters affecting quality and acceptability of the product. The changes of salt content at different days are listed in Table 1 and shown 
Am. J. Applied Sci., 6 (4): 551-554, 2009

Table 1: Time effect on the cheese properties made with Jiben seeds extract and rennet extract during storage at $30^{\circ} \mathrm{C}$ or $5^{\circ} \mathrm{C}$

\begin{tabular}{|c|c|c|c|c|c|c|c|c|c|c|c|c|c|c|c|c|}
\hline \multirow[b]{3}{*}{ Enz. Type } & \multicolumn{4}{|c|}{$\mathrm{pH}$} & \multicolumn{4}{|c|}{ Salt (\%) } & \multicolumn{4}{|c|}{ Fat (\%) } & \multicolumn{4}{|c|}{ Protein $(\%)$} \\
\hline & \multicolumn{2}{|c|}{$\begin{array}{l}\text { J. seeds } \\
\text { extract }\end{array}$} & \multicolumn{2}{|c|}{$\begin{array}{l}\text { Rennet } \\
\text { extract }\end{array}$} & \multicolumn{2}{|c|}{$\begin{array}{l}\text { J. seeds } \\
\text { extract }\end{array}$} & \multicolumn{2}{|c|}{$\begin{array}{l}\text { Rennet } \\
\text { extract }\end{array}$} & \multicolumn{2}{|l|}{$\begin{array}{l}\text { J. seeds } \\
\text { extract }\end{array}$} & \multicolumn{2}{|c|}{$\begin{array}{l}\text { Rennet } \\
\text { extract }\end{array}$} & \multicolumn{2}{|c|}{$\begin{array}{l}\text { J. seeds } \\
\text { extract }\end{array}$} & \multicolumn{2}{|c|}{$\begin{array}{l}\text { Rennet } \\
\text { extract }\end{array}$} \\
\hline & at 30 & at $5^{\circ} \mathrm{C}$ & at 30 & at $5^{\circ} \mathrm{C}$ & at 30 & at $5^{\circ} \mathrm{C}$ & at 30 & at $5^{\circ} \mathrm{C}$ & at 30 & at $5^{\circ} \mathrm{C}$ & at 30 & at $5^{\circ} \mathrm{C}$ & at 30 & at $5^{\circ} \mathrm{C}$ & at 30 & at $5^{\circ} \mathrm{C}$ \\
\hline$\overline{0.0}$ & 5.100 & 5.1 & 5.4 & 5.4 & 0.000 & 0.0 & 0.0 & 0.0 & 18.000 & 18.0 & 18.0 & 18.0 & 13.900 & 13.9 & 13.2 & 13.2 \\
\hline 15 & 5.000 & 5.0 & 5.2 & 5.2 & 10.00 & 9.5 & 10.0 & 9.4 & 16.300 & 17.2 & 16.2 & 16.6 & 13.000 & 12.8 & 12.3 & 12.7 \\
\hline 30 & 5.000 & 5.0 & 5.0 & 5.3 & 7.800 & 7.6 & 8.1 & 7.9 & 15.200 & 16.4 & 15.0 & 15.7 & 12.000 & 12.0 & 11.5 & 12.4 \\
\hline 45 & 5.100 & 5.8 & 5.3 & 5.3 & 6.100 & 6.4 & 6.2 & 6.4 & 15.400 & 16.5 & 15.5 & 15.8 & 11.900 & 12.0 & 11.3 & 12.0 \\
\hline 60 & 5.300 & 5.9 & 5.8 & 6.0 & 5.000 & 5.3 & 5.1 & 5.4 & 15.700 & 16.6 & 15.8 & 15.9 & 11.200 & 11.6 & 11.3 & 12.1 \\
\hline 75 & 5.000 & 5.7 & 5.9 & 5.5 & 4.500 & 5.0 & 4.2 & 4.9 & 16.000 & 16.6 & 16.1 & 16.0 & 11.000 & 11.5 & 11.0 & 12.0 \\
\hline 90 & 5.000 & 5.7 & 4.8 & 5.6 & 3.900 & 4.4 & 3.9 & 4.6 & 16.300 & 16.6 & 16.4 & 16.3 & 10.800 & 11.5 & 10.9 & 11.9 \\
\hline 120 & 4.400 & 5.6 & 4.7 & 5.6 & 3.900 & 4.4 & 3.5 & 4.3 & 16.500 & 16.9 & 16.6 & 16.6 & 10.600 & 11.4 & 10.7 & 11.8 \\
\hline 150 & 4.300 & 5.5 & 4.8 & 5.8 & 2.900 & 3.3 & 3.1 & 3.5 & 16.600 & 17.0 & 16.6 & 16.7 & 10.500 & 11.3 & 10.6 & 11.8 \\
\hline SE & 0.780 & & & & 1.700 & & & & 0.630 & & & & 0.315 & & & \\
\hline LS & - & & & & NS & & & & NS & & & & NS & & & \\
\hline LSD & 1.9 & & & & - & & & & - & & & & - & & & \\
\hline
\end{tabular}

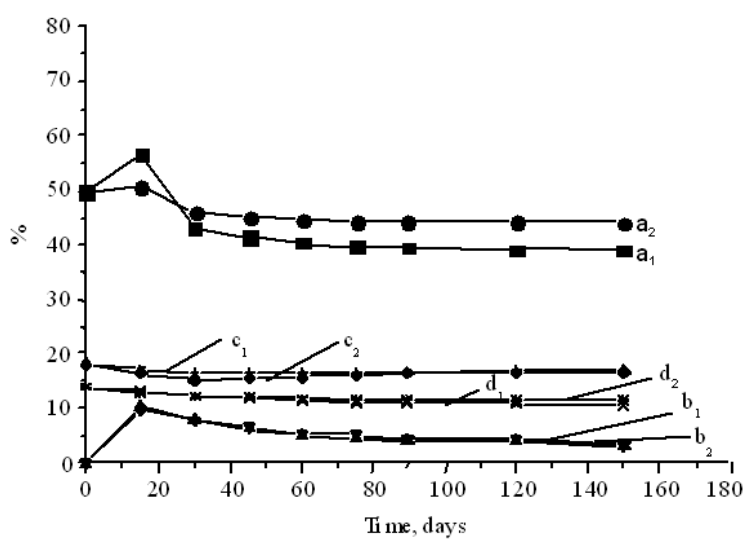

Fig. 1: Time effect on the content of moisture $\left(a_{1}, a_{2}\right)$, salt $\left(b_{1}, b_{2}\right)$, fat $\left(c_{1}, c_{2}\right)$ and protein $\left(d_{1}, d_{2}\right)$ in white cheese, prepared with Jiben Seeds extract, Kept at $30^{\circ} \mathrm{C}$ and in refrigerator at $5^{\circ} \mathrm{C}$, respectively

in Fig. 1 and 2, curves $b_{1}$ and $b_{2}$ indicate that, the salt content of the fresh cheese made either with Jiben seeds or rennet extract at zero time was zero, but after 15 days reached 10.05 and $9.45 \%$ at room temperature and in refrigerator, respectively. Salt uptake decreased gradually with time. The final salt in white pickled cheese was targeted around 3.4 and $3.9 \%$ in cheeses made with Jiben or rennet extract respectively. The results are in agreement with those of several authors ${ }^{[3,22]}$. They related the decrease in salt content of the cheese to the dissolution of cheese salt into the pickling whey to obtain equilibrium ${ }^{[3]}$ and they reported that ${ }^{[22]}$, the salt concentration was high near the brining surface and decreased toward the back surface, where it was low.

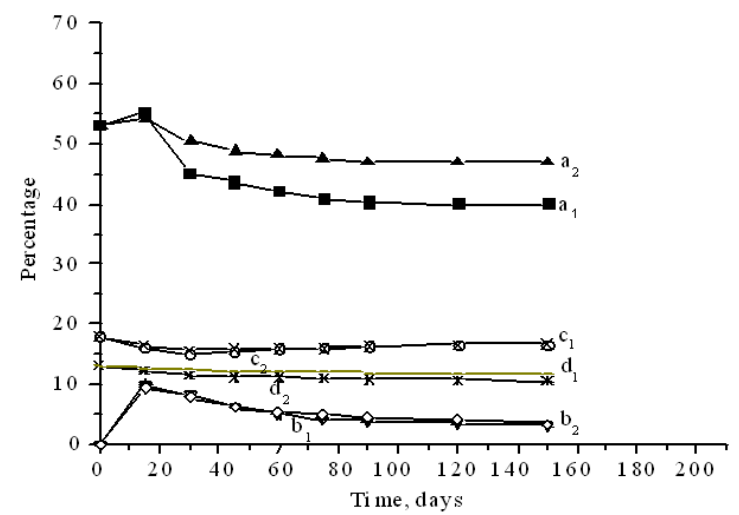

Fig. 2: Time effect on the content of moisture $\left(a_{1}, a_{2}\right)$, salt $\left(b_{1}, b_{2}\right)$, fat $\left(c_{1}, c_{2}\right)$ and protein $\left(d_{1}, d_{2}\right)$ in white cheese, prepared with Rennet extract, Kept at $30^{\circ} \mathrm{C}$ and in refrigerator at $5^{\circ} \mathrm{C}$, respectively.

Fat: Fat contents during pickling of cheeses are presented in Table 1. The mean values of fat in cheeses, prepared with Jiben seeds and rennet extract were 18.03 and $18 \%$, respectively.

After 30 days were 15.2 and $15 \%$. The drop in fat contents followed by a gradual increase as shown in Fig. 1 and 2, curves $c_{1}$ and $c_{2}$. This change was attributed to the uptake of salts as well as breakdown of fat and the continuous loss of the degraded components of cheese into brine ${ }^{[23]}$. The range of fat contents was $15-18 \%$. This range is in agreement with that found by Prasad and Alvare ${ }^{[5]}$. Increase of fat contents in cheese also found by Kebary and Co-Workers ${ }^{[24]}$.

Protein: Curves $d_{1}$ and $d_{2}$ in Fig. 1 and 2, represent the change in protein contents with time. The behavior of these curves indicates that, the protein contents in all cheese samples were slightly decreased with time as 
listed in Table 1. The behaviors also indicate that, the differences in Protein contents in cheeses prepared with Jiben seeds or with rennet extract, kept at room temperature or in the refrigerator were small. Our results and their statistical results, listed in Table 1 are similar to those found ${ }^{[3,5,25,26]}$. They reported that decrease in protein content during pickling as a result of protein degradation leading to the formation of water soluble compound and some of which lost in the pickling solution leading to increase of nitrogen content in whey ${ }^{[3,25,26]}$.

\section{CONCLUSION}

In conclusion, it could be concluded that Jiben seeds extract, which used to prepare white cheese was suitable as compared with rennet extract. In addition, Jiben seeds extract is less expansive than other coagulant to manufacture white cheese.

\section{REFERENCES}

1. Al-Jedah, J.H., R.K. Robinson, 2000. The chemical composition and microbiological quality of some white-brined cheeses on sale in Qatar. Egyptian Egypt. J. Dairy Sci., 29: 325.

2. O’Connor, C.B., 1993. Traditional Cheese Making Manual. International Livestock Center for Africa, Addis Ababa, Ethiopia, pp: 58-61, 77-78.

3. Abdalla, O.M., P.M. Davison and G.L. Christen, 1993.Survival of selected genic bacteria in white pickled cheese made with lactic acid bacteria or antimicrobials. J. Food Protect., 56: 972.

4. Mehaia, A.M., 1993. Fresh soft white cheese domiati-type) from camel milk: Composition yield and sensory evaluation. J. Dairy Sci., 76: 2845.

5. Prasad, N. and V.B. Alvarez, 1999. Effect of salt and chymosin on the physicochemical properties of feta cheese during ripening. Ibid, 82: 1061.

6. Gouda, A., 1990. Studies on chicken pepsin III storage stability and thermal-inactivation Egypt. J. Food Sci., 18: 291.

7. Craw, R.J., 1983. Future development in rennet and its use in the cheese factory, Int. Dairy Federat., Brussels, Belgium, 194: 14.

8. Steel, R.G.D. and J.H. Torrie, 1960. Principle and Procedures of Statistics. McGrow Hill Book. Company Inc., New York, USA.

9. Vogel, A.I., 1978. A Textbook of Quantitative Inorganic Analysis. 4th Edn., Longman, London.

10. Yousif, B.H., D.J. McMabon and K.M. Shammet, 1996. Milk Clotting Enzyme from Solanum dubium Plant Int. Dairy. J., 6: 637.
11. Lillie, R.D., 1945. Histopathdogic Techinque. Blakiston I'biladelphia and Toronto.

12. Talib, M.A., M.M Abubakar and I.A Jideani 2006. Effect of different concentrations of jiben (Solanum dubium) seed exracts on the physicochemical and organoleptic properties of soft cheese. J. Agric. Sci. Mansoura., Egypt., 31: 6951 .

13. Pearson, D., 1973 The chemical Analysis of Food. 6th Edn., Chemical Publishing Co., Inc., New York, pp: 499.

14. Garvie, E.I. and I.A.E. Farrow, 1982. Int. J. Syst. Bacteriol., 32: 453.

15. Ibrahim, G.F., A.K. Baldock, D.R. Bradford and L.B. Ircaland, 1981. J. Food Port., 44: 263.

16. Khalid, S.A. and E.W. Harrigan, 1984. LebensmWiss. Technol., 17: 99.

17. Abdalla, O.M, G.L. Christen and P.M. Davidson, 1993. Chemical composition of listeria monocytogenes survival in white pickled cheese. J. Food Prot., 56: 841.

18. Kenkel, J., 1994. Analytical Chemistry for Technicians. 2nd Edn. Lewis Publishers, London.

19. El-Shami, N.A., M.H. El-Gazzar and A. AbuKheir, 1981. Agric. Res. Rev., 59: 311.

20. Wahba, A. and F. El-Abbasy, 1982. Manufacture of kareish cheese without starter I: The use of lactic acid, acetic acid and hydrochloric acid. Egypt. J. Diary Sci.., 10: 61.

21. Ibrahim, M.K., M.A. El-Assar, Sh. G. Osman and W.M. Salama, 2001. Manufacture of low fat soft cheese enriched with whey protein concentrate. Ibid, 29: 107.

22. Robinson, R.K. and A.Y. Tamine, 1991. Traditional Feta Cheese and Manufactory of Feta Cheese. In: Feta and Related Cheeses, Ellis Harwood Ltd., London, pp: 11-61.

23. Metwalli, N.H., S.I. Shalabi, A.S. Zahran and O. El Demerdash, 1982. The use of soy bean milk in soft cheese making I- effect of soy bean milk on rennet coagulation property of milk. J. Food Technol., 17: 71 .

24. Kebary, K.M., A.E. Khader, A.N. Zedan and S.F. Mohmoud, 1996. Accelerated ripening of low fat ras cheese by attenuated lactobacilli cells. Food Res. Int., 29: 705.

25. Metwalli, N.H., S.I. Shalabi, A.S. Zahran and O. El-Demerdash, 1982. The use of soy bean milk in soft cheese making I- effect of soy bean milk on rennet coagulation property of milk. J. Food Technol., 17: 297.

26. Abd-El-Salam, M.H., 1993. Domiati and feta type cheeses. Cheese Chem. Phys. Microbiol., 2: 304. 